\section{First, teach the teachers}

SIR - When I started teaching, I thought teachers of English were to blame for poor scientific writing. Forty years later, I believe the main blame lies with teachers of science.

Much of what is said in lectures goes into students' notes without alteration of wording. Indeed, some teachers still write chunks of prose on the blackboard or on overhead transparencies, to ensure that students get it down correctly (my italics). I do not wish to debate whether that is good lecturing technique. My point is that lecturers' linguistic packaging of their subject-matter is something that students are likely to imitate and sometimes are obliged to copy.

The written items that accompany lectures are especially powerful influences. Handouts, example sheets, annotations on slides or charts - all these apparently represent the teacher's judgement of good ways to marshal and encode the material being studied. They are obvious sources of verbatim borrowings. Those borrowings become the currency of exchange in tutorial discussions, essays and examination answers. They begin to influence the mental set and the patterns of expression adopted by students.

If the models of accuracy, coherence and readability presented by teachers are good, the language training they give by example is beneficial. If the models they present are poor, their effect is pernicious. If the teachers themselves have little understanding of how language works, and of how to write readably, they are ill-equipped to evaluate students' writing and to show how that writing might be improved.

We have research-based knowledge of how to present scientific information accurately, readably and in styles that scientists themselves prefer to read. Unfortunately, many science teachers either are unaware of that knowledge or ignore it. Instead, they cling to the superstitions encapsulated by Simon Leather's letter "The case for the passive voice" (Nature 381, 467; 1996). Those superstitions are immensely influential. Time and again, young scientists, including young university teachers, have told me that they accept the findings of research into the readability of scientific writing, but that they dare not depart from 'traditional' passive, impersonal style for fear of their work being rejected by journal editors and by Leatherian academic supervisors. Given the points-scoring procedures that now affect survival in British universities, that fear is legitimate and serious.

How can we improve the situation? First, journal editors must remove the mythology that surrounds what they will and will not accept. A valuable step would be for all editors to stress that their Notes for Authors specify structure and format but not 'traditional' style. I do not know of any Notes for
Authors that specify or even recommend third-person, passive-voice writing for scientific papers.

Second, university science departments should jointly establish a programme in which staff could explore the research evidence on how to express scientific information accurately and readably. We need a joint initiative from senior academics, preferably supported by scientists in industry, to show new recruits that Leatherian views are not the views of the majority of the scientific community. Only when they are confident of that fact will young scientists, including university teachers, risk using and teaching anything other than 'traditional' turgid style.

\section{John Kirkman}

Witcha Cottage,

Ramsbury,

Marlborough,

Wiltshire SN8 2HQ, UK

\section{All the lab's a stage}

SIR - John Emsley observes, in his review of the play Blinded by the Sun (Nature 383, $312 ; 1996)$, that during the past half century chemistry "has been almost ignored by writers and dramatists". Perhaps, but at least one offering merits mention.

The author is the Columbia University biochemist Erwin Chargaff, discoverer of the nucleotide-binding rules that bear his name - that adenine binds to thymine, and guanine to cytosine. The play (Amphisbae$n a$, in Voices in the Labyrinth: Nature, Man and Science, by Erwin Chargaff; Seabury Press, New York, 1977) takes the form of a dialogue between an Old Chemist (transparently Chargaff himself) and a Young Biologist (James D. Watson, co-discoverer of the double-stranded helical structure of DNA) on the tension between chemistry and biology, and on the nature of scientific revolutions.

The dialogue is deliciously mordant, with such lines as "molecular biology is essentially the practice of biochemistry without a licence" and "life is what's lost in the test tube". And on the subject of some researchers winning and others losing in the quest for scientific immortality, the author concludes that "to make a scientific revolution one must break many eggheads".

Amphisbaena is still a timely commentary — and a good read.

\section{Henry I. Miller}

Hoover Institution and Institute

for International Studies,

Stanford University,

Stanford,

California 94305-6010, USA

e-mail: miller@hoover.stanford.edu
Divided by a common language

SIR - It is true that searching for data in bibliographic databases is greatly hampered by the differences between US and British spelling. It is also true that this problem will cause increasing problems in the future.

Koreaki Ito, in proposing the adoption of a universal spelling, correctly states that this would imply abandoning either British or American spelling (Nature 382, 666; 1996). $\mathrm{He}$ prefers the former option because he considers it more feasible, on the basis of figures that he does not detail. Is that because Japan (where Ito lives) is more oriented towards the United States than to Britain? Possibly so, although Ito probably does not intend to discriminate against Britain. I nevertheless dispute his preference for US spelling.

As a professional scientific editor, I find that British authors do, as a rule, object if their British English is changed into American English. Americans, on the other hand, rarely object if their texts are adapted to conform to British English. This may be an emotional reason to adhere to the British English spelling.

More important, however, is my observation that spelling in American English seems to be less consistent than in British spelling. Not only do American authors as a group spell words in different ways, but an American author may write the same word differently even within one manuscript. Opting for American English will not rule out the problem of different spellings, which is Ito's objective. It may be true that some spelling differences also exist in British English, but these differences are almost negligible when compared to the differences that can be found in American texts.

If science should opt for a universal English spelling - and I agree with Ito that it should do so as soon as possible - experts in each specific discipline should be consulted, as well as language experts. Many more spelling problems exist than Ito may be aware of. He mentions 'disulfide' and 'disulphide' to exemplify the problem: I have found, in one of the numerous chemical databases, for one single compound, the following terms: $\mathrm{SO}_{2}, \mathrm{SO} 2$, sulfur dioxide, sulphur dioxide, sulfur dioxyde and sulphur dioxyde.

Eliminating such sources of confusion is most important. It would be necessary also to try to rule out synonyms, which pose a comparable problem when searching a bibliographic database.

A task for the International Council of Scientific Unions (ICSU), perhaps?

\section{A. J. van Loon}

(Vice-president European Association

of Science Editors (EASE))

Benedendorpsweg 61,

6862 WC Oosterbeek,

The Netherlands 